\title{
GEOGRAPHY RULES TOO! ECONOMIC DEVELOPMENT AND THE GEOGRAPHY OF INSTITUTIONS
}

\author{
MAARTEN BOSKER \\ HARRY GARRETSEN
}

CESIFO WORKING PAPER NO. 1769

CATEGORY 5: FisCAL POLICY, MACROECONOMICS AND GROWTH

JULY 2006

An electronic version of the paper may be downloaded

- from the SSRN website:

- from the RePEc website:

- from the CESifo website:

www.SSRN.com

www.RePEc.org

www.CESifo-group.de 


\title{
GEOGRAPHY RULES TOO! ECONOMIC DEVELOPMENT AND THE GEOGRAPHY OF INSTITUTIONS
}

\begin{abstract}
To explain cross-country income differences, research has recently focused on the so-called deep determinants of economic development, notably institutions and geography. This paper sheds a different light on these determinants. We use spatial econometrics to analyse the importance of the geography of institutions. We show that it is not only absolute geography, in terms of for instance climate, but also relative geography, the spatial linkages between countries, that matters for a country's gdp per capita. Apart from a country's own institutions, institutions in neighboring countries turn out to be relevant as well. This finding is robust to various alternative specifications.
\end{abstract}

JEL Code: O11, F43.

Maarten Bosker

Utrecht School of Economics

Utrecht University

Vredenburg 138

3511 BG Utrecht

The Netherlands

m.bosker@econ.uu.nl
Harry Garretsen

Utrecht School of Economics

Utrecht University

Vredenburg 138

3511 BG Utrecht

The Netherlands

h.garretsen@econ.uu.nl

We would like to thank Rob Alessie, Steven Brakman, Gerrit Faber, Bernard Fingleton, Raymond Florax, Henri de Groot, Thijs Knaap, Joppe de Ree, Hein Roelfsema, Stephen Redding, Marc Schramm and seminar participants in Rome and Amsterdam for useful comments and suggestions. 


\section{Introduction}

The question why we observe such large income differences between countries is arguably the most important question in economics. Lately, research on this issue has focused on the socalled deep or fundamental determinants of economic development. Three determinants have been singled out, institutions, geography, and economic integration (openness). Papers by inter alia Hall and Jones (1999), Acemoglu, Robinson and Johnson (2001), Easterly and Levine (2003) and Rodrik, Subramanian and Trebbi (2004) present strong, though not undisputed, empirical evidence in favour of institutions over geography and openness. Or in the words of Rodrik et al. (2004): institutions rule! Openness is deemed irrelevant and geography has at most an indirect impact, via institutions, on per capita income levels. The goal of the present paper is to extend this line of research by allowing geography to play a different role. Instead of defining a country's geography only in absolute terms, that is independent from the location and characteristics of other countries, we also look upon geography in relative terms. The latter implies that a country 's prosperity is not only a function of its own deep determinants but potentially also of these determinants in other countries.

Instead of merely analysing whether or not a country is better off if surrounded by highincome neighbors (see e.g. Redding and Venables, 2004 and Easterly and Levine, 1998), we take the observation that institutions rule as our starting point and show that it is the geography of institutions that matters. The institutions of other (neighboring) countries exert a significant impact on a country's own gdp per capita. This is the main finding of our paper and we show that it is robust to alternative measures of geography, alternative samples and a varying list of controls. The second contribution of this paper is that we use spatial econometrics to analyse the geography of institutions and other spatial variables, like spatial gdp. In our view, spatial econometrics is a useful tool in the IV-setting that characterises the new or, if one likes, deep growth empirics.

The paper is organized as follows. Section 2 briefly discusses the recent literature on the relevance of the so-called deep determinants of economic development, notably institutions and geography, and it motivates our choice to look at the spatial or geographical nature of institutions. In section 3 we present our data set along with some descriptive statistics and we 
also introduce our main specification and the spatial econometrics involved in the estimation process. Section 4 discusses the estimation results. Finally, Section 5 concludes.

\section{The Deep Determinants of Income and the Role of Geography}

Income differences between countries are large and persistent. To explain these differences, economists have traditionally called upon growth theory and have used growth regressions where factor inputs and factor productivities are the prime explanatory variables. As Rodrik et al. (2004, pp. 132-133) emphasize, the basic problem with this standard approach is that it is merely concerned with the proximate causes of economic growth. If it is for instance found that income differences are due to differences in labour productivity, this is begging the question what drives the latter. To explain income differences, we therefore need to understand the deep or fundamental determinants of economic growth. In the recent empirical literature on the fundamental causes of income or growth differences, three deep determinants have in particular been emphasized: institutions, geography and economic integration. A main stimulus for what might be called the new growth empirics is the use of instruments that deal with the endogeneity issue. To be able to conclude that cross-country variations in these kind of deep determinants "cause" the observed cross-country income differences, one wants to exclude the feedback from income or a third variable of interest. Since geography is meant to refer to physical geography only, the exogeneity of this determinant is commonly taken for granted. This is however not true for institutions or economic integration (openness) and it is here that the introduction of new instruments has been important. Following the work of notably Acemoglu et al. (2001), Hall and Jones (1999) and Frankel and Romer (1999), the issue of the instrumentation of respectively institutions and economic integration can be dealt with. Even though there are differences in the specifications used and in the deep determinants actually included in the analysis (any combination of institutions, geography or integration can be found in the literature), the main conclusion is that institutions have a strong and direct impact on income, that geography is at best only of indirect importance to explain income differences (via its impact on institutions), and that economic integration, when set against institutions and geography, does not have a significant impact on income. This consensus view is best exemplified by the seminal paper by Rodrik et al. (2004) that will therefore serve as a benchmark for our own analysis.

The methodology used and the conclusions reached by Rodrik et al. (2004) and other related papers have, however, not remained unchallenged. Sachs (2003) for instance strongly disputes 
the alleged irrelevance of physical geography and attempts to show that alternative measures of geography (i.e. tropical disease indicators) indicate that geography is as important as institutions. Glaeser et al. (2004) argue that institutions are poorly measured and identified in the new growth empirics and once this is acknowledged, other and more standard determinants (human capital) are far more important in explaining differences in economic prosperity. As to the conclusion that economic integration or openness is not important, Alcala and Ciccone (2004) for instance use an alternative measure of openness and then show that openness is very significant in explaining cross-country differences in productivity. ${ }^{2}$

In our view, the new or deep growth empirics can, however, be criticized for a different and more fundamental reason. Our criticism deals not with the exact definitions of the three deep determinants of income in Rodrik et al. (2004), our concern is first and foremost with the limited role that second nature geography or space plays in the analysis. Following a distinction made by Krugman (1993), the current literature only looks at the role of first nature or absolute geography (e.g. looking at the impact of variables such as distance to the equator, climate, or disease environment) in explaining cross-country income differences. Second nature geography does not play a part at all. As a result, the relative geography of a country, i.e. the location of a country vis-à-vis other countries (in our view also clearly a deep determinant) is no issue. This neglect not only holds for economic interdependencies but also for political and, most relevant here, institutional interdependencies that may exist between (neighboring) countries. It is only differences in absolute geography between otherwise spatially independent countries that matter. So, for the income of country $j$ only the geography in terms of its own climate or its access to the sea is thought to be important but not whether or not this country is surrounded by countries with a high income level and/or good institutions nor whether or not it located near large markets and/or its main suppliers.

The idea that second nature geography is relevant has already been given some attention in the literature. It lies at the heart of for instance the so-called new economic geography approach (Fujita et al., 1999). In a nutshell and when applied to this paper's topic, this approach argues that a country's income is higher if this country is located close to other high-income countries. Papers by Crafts and Venables (2001) and Redding and Venables

\footnotetext{
${ }^{2}$ See section 2.3 in Rodrik et al (2004) for a reaction to Sachs (2003) and Alcala and Ciccone (2004). Another recent critique, see for instance Rajan and Zingales (2006), is whether institutions can really be considered to be deep determinants to begin with.
} 
(2004) provide empirical evidence that this indeed seems to be the case (see also section 4.3 below). This paper takes a somewhat different approach. Given the aforementioned consensus in the literature, we include the institutions of neighboring countries. More in particular, we want to find out if the geography of institutions matters to understand crosscountry income differences. Several authors have discussed channels (see also Table 8 below) through which the institutional setup in neighboring countries may be of importance. Easterly and Levine (1998) show that the poor economic performance of one country (as a result of for instance bad policy) negatively affects income levels in its neighboring countries. Ades and Chua (1997) provide evidence that instability in neighboring countries (measured by the number of revolutions and coups) has a negative effect on the economic performance of a country itself. Regional instability disrupts trade, especially for landlocked countries that are depending on trade routes (access to the sea) through neighboring territory. It also results in increased military expenditures to prevent spreading of conflict and/or to deter potential future military aggression from unstable neighbors (thereby crowding out productive investment by the government). In a similar vein, Murdoch and Sandler (2002) argue that civil war in neighboring countries disrupts economic activity at home. Finally, Simmons and Elkins (2004) show that countries copy (avoid) policies (be it bad or good) from other (neighboring) countries that were proven (un)succesful or that countries are forced to adopt similar policies as those in other countries in order to stay economically competitive or in order to comply to regional or global pressures.

\section{Model Specification, Data Set and Estimation Strategy}

\subsection{Model Specification}

Following the exposition in Rodrik et al. (2004) the benchmark empirical specification of this paper is the following equation:

ii) $y_{i}=\alpha+\beta G e o_{i}+\gamma$ Inst $_{i}+\varepsilon_{i}$

i) Inst $_{i}=\mu+\phi Z_{i}+\delta G e o_{i}+\eta_{i}$

where $y_{i}$ is the natural logarithm of income per capita in country $i$, Inst $t_{i}$ and $G e_{i}$ are measures for institutions and geography respectively, and $\varepsilon_{i}$ is a random error term. Furthermore $Z_{i}$ is a vector (or vectors) of variables used to instrument the measure for institutions to correct for potential reverse causality (higher income results in better institutions), omitted variables or measurement error. Rodrik et al. (2004) use, following Acemoglu et al. (2001), European settler mortality as only instrument for their baseline sample. Given the resulting limitation that this imposes on the number of countries (79 former colonies) that can be included in the 
analysis, they also resort to the use of two other instruments, introduced by Hall and Jones (1999), i.e. \% population speaking English and \% population speaking a European language, and consider a much larger sample of 137 countries $^{3}$.

To incorporate the main point of this paper in the empirical specification, we add a term capturing the quality of institutions of one's neighbors to equation (1):

$$
\begin{array}{cc}
\text { ii) } & y_{i}=\alpha+\beta G e o_{i}+\gamma \text { Inst }_{i}+\lambda(\text { W Inst })_{i}+\varepsilon_{i} \\
\text { i) } & \text { Inst }_{i}=\mu+\phi Z_{i}+\delta G e o_{i}+\eta_{i}
\end{array}
$$

where $(W \text { Inst })_{i}$ is a measure of the average quality of institutions in country $i^{6}$ s neighboring countries. More formally this measure is constructed by matrix multiplication of the so-called spatial weights matrix, $W$, with the vector of own country institutions, Inst. Equation (2) captures the main idea of this paper quite clearly. An institutional change in country $i$ not only has an effect on the economic prosperity of country $i$ itself $\left(\partial y_{i} / \partial I_{n s t}=\gamma\right)$ but also on that of its neighbors $\left(\partial y_{j} / \partial \operatorname{Inst}_{i}=\lambda w_{j i}\right)$.

The simplest way to construct the spatial weight matrix is based on contiguity, or more formally:

$$
w_{i j}=\left\{\begin{array}{cl}
1 / n & \text { if country } i \text { and } j \text { share a common border } \\
0 & \text { otherwise }
\end{array}\right.
$$

where $n$ is the total number of neighbors of country $i$ (islands are assigned their nearest neighbor in terms of distance between capital cities as being their only contiguous neighbor). We have decided to use this simple contiguity based weighting matrix, which gives equal weight to all neighbors, as our baseline specification (also used by Ades and Chua, 1997). Other weighting schemes have been used in the literature on spillovers between neighboring countries however, for example weighting each neighbor by the size of its total GDP (Easterly and Levine, 1998), weighting each neighbor by the length of the common border (Murdoch and Sandler, 2002) or by considering the n-nearest countries as being neighbors. We use the simple spatial weight matrix in (3) in our baseline specification ${ }^{4}$ as we think it captures in a clean and simple way the main point that we want to make in this paper, namely that $2^{\text {nd }}$

\footnotetext{
${ }^{3}$ The use of these two instruments for their largest sample is not without problems, see Appendix B.

${ }^{4}$ In section 4.2 we assess the robustness of our results by using alternative spatial weight matrices. Note also that the use of GDP weights is likely to result in an endogenous spatial weight matrix, making inference problematic (see Anselin, 1988).
} 
nature or relative geography matters ${ }^{5}$. As in equation (1), institutions need to be instrumented as well in order to resolve potential endogeneity problems, see section 3.3 below.

\subsection{The Data Set}

Regarding the choice of variables for institutions and geography we also follow Rodrik et al. (2004) by taking the Rule of Law variable due to Kaufmann et al. (2005) ${ }^{6}$ as our baseline institutional measure and the absolute distance from the equator in degrees as our baseline geography measure. As dependent variable we collected GDP per capita (PPP adjusted) in 1995 from the 2003 version of the World Development Indicators.

Figure 1 The spatial distribution of (a) GDP per capita and (b) Institutions (Rule of Law)

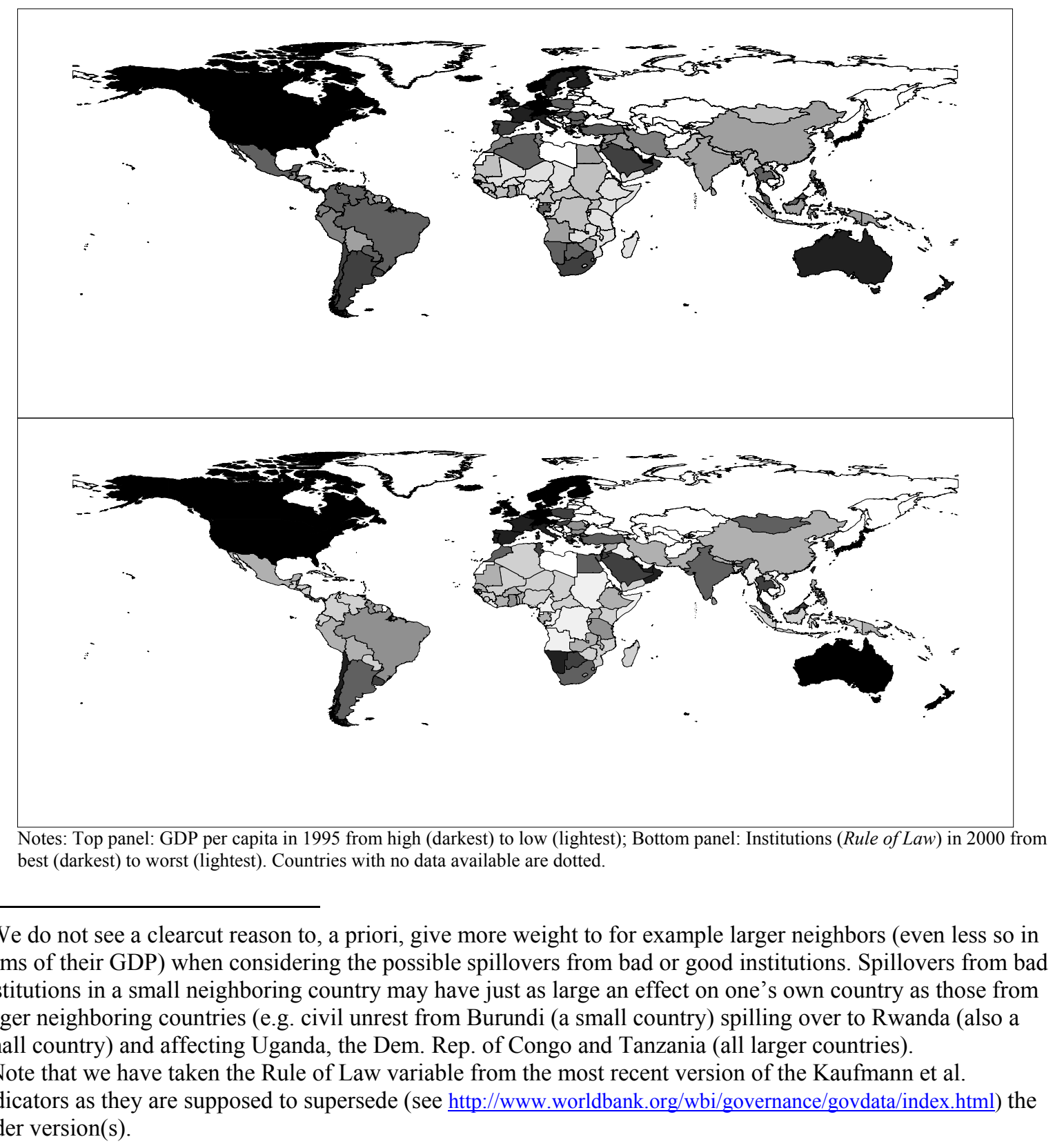


To give an idea of the spatial distribution of both GDP per capita and institutions, Figures 1a and $1 \mathrm{~b}$ show the distributions of these two variables across the countries in our dataset. As can be seen both income per capita and the quality of institutions are not randomly distributed across the globe. Instead, relatively high (low) levels of income per capita are geographically clustered in the Americas and Europe (Africa and Asia) and clusters of relatively good (bad) institutions are located in North America, Europe and the southern tip of Africa and South America (Africa, Middle- and South America and part of the Middle-East). Whereas the current literature implicitly explains this clustering of similar income levels by countryspecific differences in e.g. $1^{\text {st }}$ nature geography and institutions, this paper looks whether or not this spatial pattern of institutions also contributes to the observed income differences.

Table 1 Descriptive Statistics for the main variables of interest

\begin{tabular}{|c|c|c|c|c|}
\hline \multicolumn{5}{|c|}{ Number of countries in the sample: 147} \\
\hline & GDP per capita in 1995 (PPP adjusted) & Geography & Institutions & Neighboring institutions \\
\hline Mean & I\$ $7518($ mean log y: 8.34) & 22.67 & 0.12 & 0.02 \\
\hline Standard deviation & I\$ $7230 \quad$ (s.d. log y: 1.15) & 15.52 & 1.03 & 0.92 \\
\hline Min & I\$450 (Tanzania) & 0.23 (Uganda) & .86 (Dem. Rep. Congo) & -1.72 (Seychelles) \\
\hline Max & I\$ 33256 (Luxembourg) & 63.89 (Iceland) & 2.20 (Switzerland) & 2.05 (Sweden) \\
\hline
\end{tabular}

Table 1 provides some additional descriptives. The countries in our sample have an average GDP per capita of I\$ 7518 with a large variation across countries (s.d. of I\$ 7230); ranging from I\$ 450 per capita in the poorest country (Tanzania) to I\$ 33256 per capita in the richest country (Luxembourg). The typical country is located at 22.67 degrees above or below the equator with Uganda the closest and Iceland (that is their respective centroid) the furthest away from the equator. Regarding the institutional quality measure, Table 2 and Figure 2 give some more detail about both the institutional and the neighboring institutional qualities.

\section{Table 2 (Neighboring) Institutions in more detail}

\begin{tabular}{|c|c|c|c|}
\hline $\begin{array}{c}\text { Worst } \\
\text { Institutions }\end{array}$ & $\begin{array}{c}\text { Worst } \\
\text { Neighboring Institutions }\end{array}$ & Relatively Bad Neighbors & Relatively Good Neighbors \\
\hline Dem. Rep. Congo & Seychelles (IsI) & Hong Kong (China) & Philippines (IsI -> Hong Kong) \\
\hline Somalia & Dominican Republic & Kuwait (Iraq, Saudi Arabia) & Yemen (Oman, Saudi Arabia) \\
\hline Liberia & Jamaica (|s|) & Chile (Bolivia, Peru, Argentina) & Iraq (Kuwait, Iran, Jordan) \\
\hline Iraq & Sierra Leone & Singapore (Malaysia) & Haiti (Dominican Republic) \\
\hline Haiti & Central African Rep. & Mauritius (IsI -> Madagascar) & Poland (Germany) \\
\hline
\end{tabular}


Figure 2 Scatterplot own and neighboring institutions

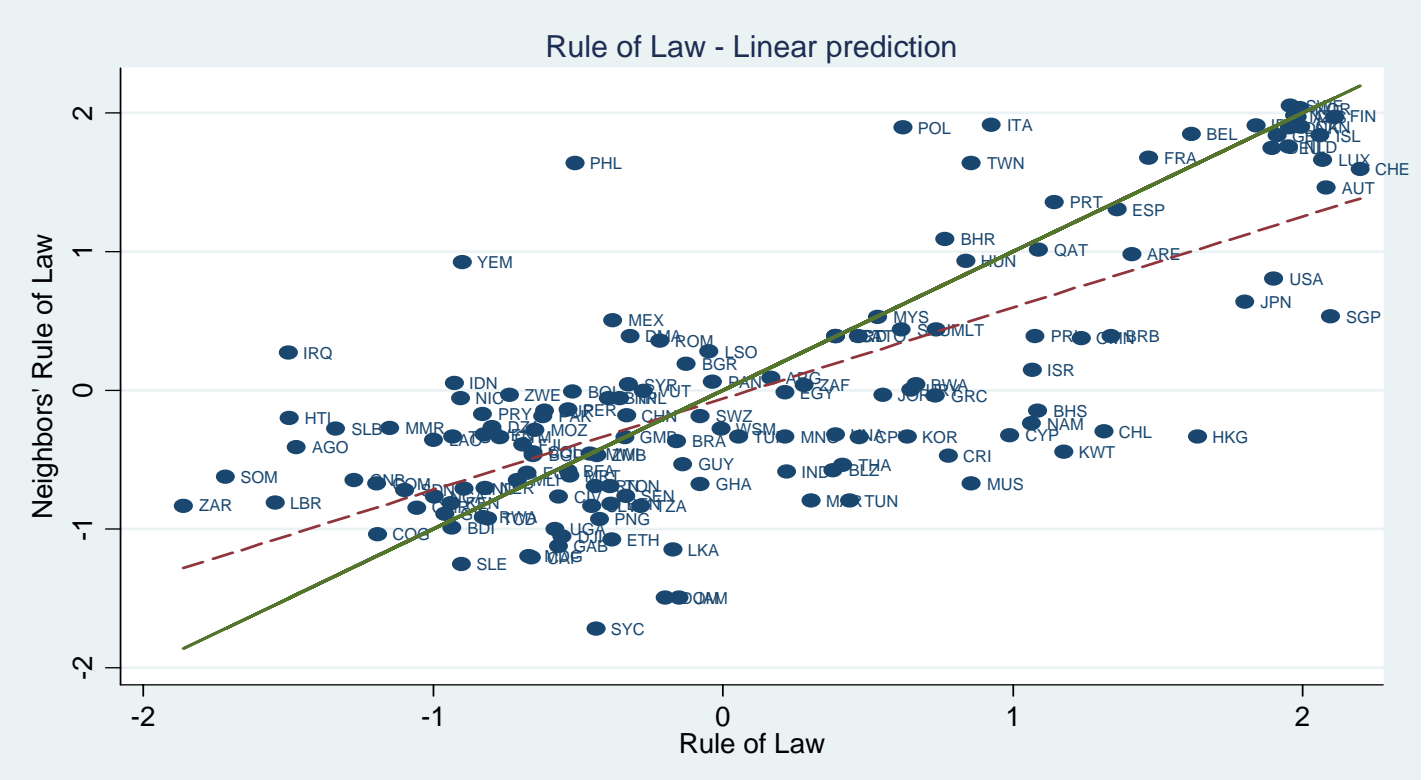

Notes: The institutional measure, Rule of Law in 2000 , ranges from -2.50 (worst) to +2.50 (best). The variable neighboring institutions is constructed as in (3) using the contiguity-based spatial weight matrix with islands being assigned their nearest neighbor (based on distance between capital cities) as only (artificial) contiguous neighbor. The simple pairwise correlation between own neighboring institutions is 0.73 [p-value: 0.00] (dotted line). The thick line is the $45^{0}$ degree line. Sample 147 countries.

Figure 2 shows the relationship between own and neighboring institutions (pairwise correlation between the two is 0.73 [p-value 0.00]). Countries below (above) the thick $45^{0}$ line are countries with better (worse) own institutions than their average neighbor. Table 2 provides some more detail on this, showing that Hong Kong (the Phillipines) has the best (worst) institutions relative to its neighbors followed by Kuwait and Chile (Yemen and Iraq). In absolute terms the Seychelles (followed by the Dominican Republic, Jamaica and Sierra Leone) have the worst neighbors in terms of institutions whereas the Democratic Republic of Congo has the worst own institutions (followed by Somalia, Liberia and Iraq).

Note that our baseline sample consists of 147 countries. Rodrik et al. (2004) use a sample of only 79 countries as their baseline sample because they deem settler mortality (taken from Acemoglu et al., 2001) to be a 'better' instrument (based on the result of overidentification tests), than the Hall and Jones (1999) instruments, i.e. \% population speaking a European language and \% population speaking English (see also Acemoglu, 2005) ${ }^{7}$. Settler mortality rates are, however, only available for 79 countries (former colonies only). Besides the more standard argument of improving inference when using more observations (see also McArthur and Sachs, 2001), we have a more fundamental reason to use the largest possible sample. Given our aim to assess the importance of $2^{\text {nd }}$ nature or relative geography, more particularly

\footnotetext{
${ }^{7}$ See Appendix B for a detailed discussion of the solution to this problem in case of our 147-country sample.
} 
the institutional setting in neighboring countries, we do need to have data available on these neighbors! To make our point, Figure 2 shows a map of the countries included in our 147country sample and also a map of the 79 countries included in Rodrik et al.'s baseline sample.

Figure 2 Our baseline sample and Rodrik et al (2004) baseline sample

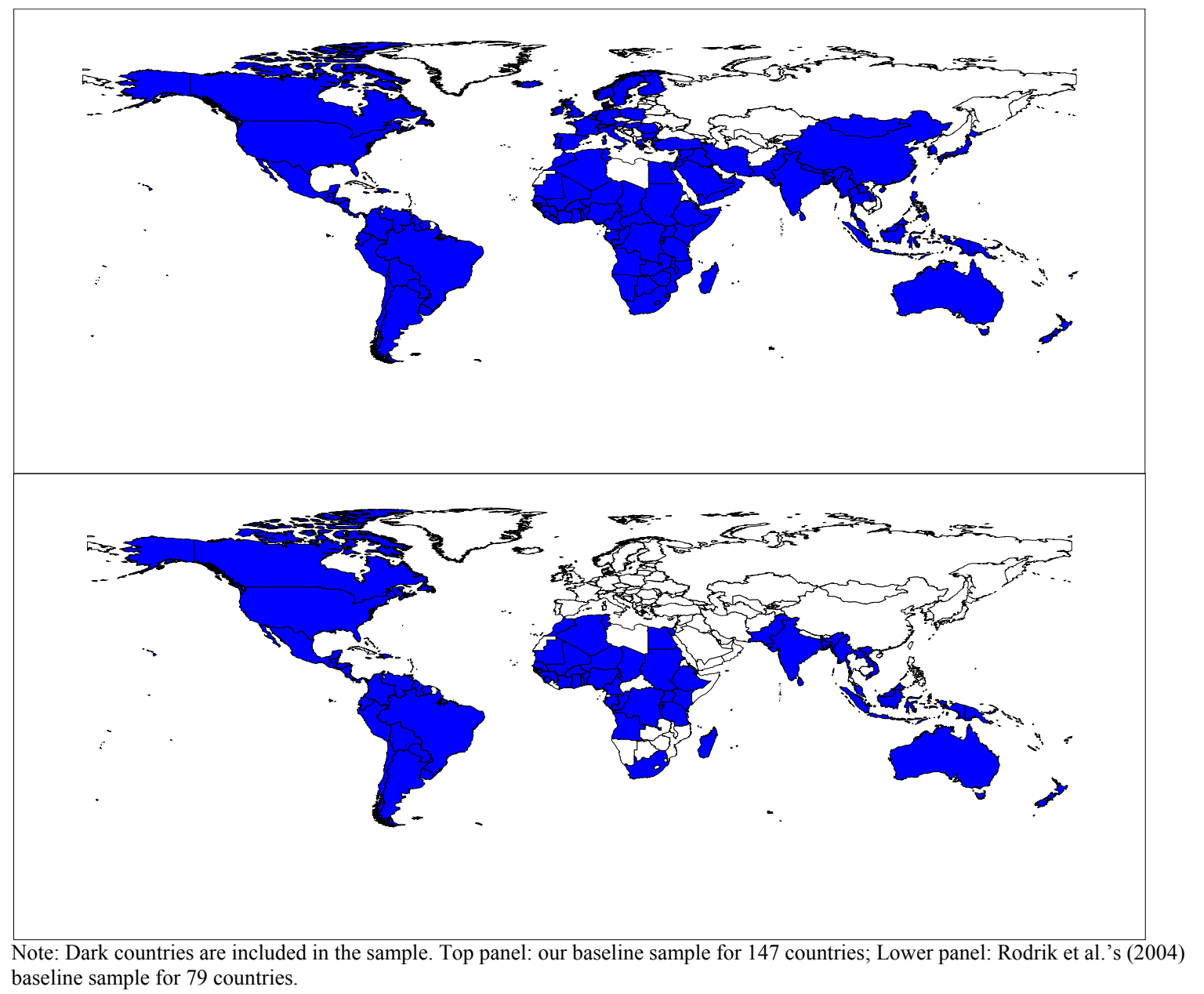

From Figure 2 it is immediately clear that the 147 sample adds many countries in Europe, the Middle-East, Asia and Africa (still missing in our sample are mainly former communist countries). Restricting our analysis to the 79 country sample would lead to a number of countries (mainly in Africa and Asia) having far fewer neighbors than they in actual fact have, e.g. Angola, Tanzania, Cameroon, India, Vietnam, Laos and Egypt, and even leads to 'artificial islands', i.e. South Africa and Hong Kong. Using the largest possible sample avoids or at least limits this problem ${ }^{8}$.

\footnotetext{
${ }^{8}$ Admittedly, the problem still remains in our sample, but too a much lesser extent (basically only for countries bordering a former communist country).
} 


\subsection{Estimation Strategy}

Given the model specification as given by equation (1), Rodrik et al. (2004) apply a 2SLS estimation procedure. Given the fact that the institutional measure is expected to be correlated to the error term due to reverse causality, measurement error or omitted variable bias, a simple OLS regression on equation (1-ii) would result in biased and inconsistent estimates of all parameters of interest. 2SLS solves these problems if a 'good' instrument(s) ${ }^{9}$ is used for the institutional quality measure. In the $1^{\text {st }}$ stage (1-i), the institutional measure is regressed on the instrument(s) and the geography measure (and possible additional controls), and in the $2^{\text {nd }}$ stage (1-ii) the effects of geography and institutions are obtained as the parameters on geography and fitted institutions from the $1^{\text {st }}$ stage, obtained by regressing log GDP per capita on the geography measure and the fitted institutions obtained from the $1^{\text {st }}$ stage (and possible additional controls), respectively.

Can one use the same estimation strategy when taking $2^{\text {nd }}$ nature geography into account by also trying to estimate the effect of neighboring countries' institutions on one's own GDP per capita? And related to this: do we also have to instrument our measure of neighboring institutions, and if so how to do this? As mentioned before, the reason to use a 2SLS estimation procedure in the standard case, our model (1), is that the institutional quality measure is likely to be correlated to the $2^{\text {nd }}$ stage error term, making OLS a biased and inconsistent estimator. More formally,

$$
E\left(\text { Inst }^{\prime} \varepsilon\right) \neq 0
$$

In our case, model (2), the need to instrument own institutions is beyond discusson given the importance given to this in the earlier literature, and we do this using the variable \% speaking a European language as an instrument. See Appendix B for more information on the estimation strategy and the choice of instruments. But here we face the additional question whether or not we also have to instrument neighboring countries' institutions. As in the case of own institutions, this variable needs to be instrumented if it is suspect to be correlated with the error term, i.e.

$$
E\left((W \text { Inst })^{\prime} \varepsilon\right) \neq 0
$$

If this is the case, instrumenting only own institutions will result in biased and inconsistent estimates not only of the effect of neighboring institutions but of all estimated parameters (so

\footnotetext{
${ }^{9}$ Good meaning 1) significantly related to the institutional quality measure, i.e. significant in the $1^{\text {st }}$ stage, and 2) uncorrelated with the residual in the $2^{\text {nd }}$ stage. The second requirement can be explained more intuitively by saying that the effect the instrument has on GDP per capita goes entirely through its effect on institutional quality.
} 
also the effect of own institutions and geography). So can we expect neighboring institutions to be correlated with the error term? As in case of own institutions there are basically three main reasons for this to be the case: reverse causality, measurement error and omitted variable bias. Appendix $\mathbf{C}$ discusses each of these potential sources of endogeneity of the neighboring institutions variable in more detail. Based on the arguments in Appendix C, it is quite likely that we do have to instrument our measure of neighboring countries' institutional quality to avoid potential endogeneity bias in our estimates. Having established this need to instrument neighboring countries' institutions, the natural follow-up question is what to use as an instrument? Does this require the introduction of a new instrument? As also shown in Appendix C, this turns out not to be the case, given that we have a valid instrument for own institutions, i.e. \% of the population speaking a European language, we can apply the following estimation strategy:

1. In the $1^{\text {st }}$ stage regress own institutions on the instrument, geography and possible additional controls, (2-i) and obtain the fitted institutions, Inst .

2. Using the obtained fitted institutions construct also neighboring countries' fitted institutions, i.e. W Inst .

3. In the $2^{\text {nd }}$ stage, (2-ii), regress GDP per capita on geography, possible additional controls and $\hat{I n s t}$ and $W$ Inst. Given the validity of the chosen instrument, the parameters obtained will be unbiased and consistent estimates of the parameters of interest.

Given the discussion above, all estimation results in the next section are obtained with the estimation strategy outlined above.

\section{Estimation Results}

\subsection{Baseline model}

As we explained in the previous section, our baseline specification closely follows the baseline specification in Rodrik et al. (2004) because we basically want to extend their analysis by adding spatial institutions. Table 3 presents the estimation results for our baseline model. The relevant comparison with the Rodrik et al. (2004) study is their Table 3. The log of gdp per capita is thus regressed on the preferred measures for geography, institutions and, in our extension, neighbouring institutions. Since a main conclusion from the Rodrik et al. (2004) study is that the integration (openness) variable is invariably insignificant, we decided to omit that variable and we thereby concentrate on the main issue for the present paper, the 
relationship between geography $\left(1^{\text {st }}\right.$ and $2^{\text {nd }}$ nature $)$ and institutions ${ }^{10}$. Columns (1)-(5) replicate the findings by Rodrik et al. (2004). Institutions are always very significant. $1^{\text {st }}$ nature geography is significant when included on its own, but ceases to be significant or is significant with the wrong (unexpected) sign once we include (instrumented) institutions. It seems to be at most of only indirect relevance, given the fact that it is significant in the $1^{\text {st }}$ stage (see column (5) and (7)). Note also that the instruments have the expected sign and are significant too ${ }^{11}$.

Table 3 Estimation results for baseline specification

\begin{tabular}{|c|c|c|c|c|c|c|c|}
\hline \multicolumn{8}{|c|}{ Baseline } \\
\hline \multicolumn{8}{|c|}{ Dependent variable: log GDP per capita in 1995} \\
\hline & (1) OLS & (2) OLS & (3) OLS & (4) 2 SLS & (5) 2 SLS & (6) OLS & (7) 2 SLS \\
\hline \multirow[t]{2}{*}{ Geography (distance equator) } & 4.21 & - & 0.59 & - & -1.76 & 0.17 & -2.45 \\
\hline & $(11.57)$ & - & $(1.55)$ & - & $(-1.94)$ & $(0.41)$ & $(-2.13)$ \\
\hline \multirow[t]{2}{*}{ Institutions (rule of law) } & - & 0.95 & 0.88 & 1.39 & 1.45 & 0.81 & 0.92 \\
\hline & - & $(24.75)$ & (15.39) & $(7.10)$ & $(7.07)$ & $(11.84)$ & $(2.75)$ \\
\hline \multirow[t]{3}{*}{ Neighboring Institutions (rule of law) } & - & - & - & - & - & 0.19 & 0.75 \\
\hline & - & - & - & - & - & $(2.17)$ & $(2.69)$ \\
\hline & \multicolumn{7}{|c|}{ 1st stage } \\
\hline Instrumented variable & na & na & na & Institutions & Institutions & na & Institutions \\
\hline \multirow[t]{2}{*}{$\%$ speaking european language } & - & - & - & 0.81 & 0.70 & - & 0.70 \\
\hline & - & - & - & $(4.12)$ & $(5.48)$ & - & $(5.48)$ \\
\hline \multirow[t]{2}{*}{ Geography (distance equator) } & - & - & - & - & 4.01 & - & 4.01 \\
\hline & - & - & - & - & $(12.72)$ & - & $(12.72)$ \\
\hline nr observations & 147 & 147 & 147 & 147 & 147 & 147 & 147 \\
\hline
\end{tabular}

Notes: t-values in parentheses.

Our principal interest in Table 3 is, however, with columns (6) and (7). Two results stand out. First, neighboring institutions matter. Neighboring institutional quality has a significant positive effect on economic prosperity. Second, a country's own institutions continue to be relevant but, when including also neighboring institutional quality, the estimated coefficient is lower compared to the 2SLS results in column (5). The estimated effect of own institutions is however (not unexpectedly) larger than that of neighboring institutions, even more so when one keeps in mind that the estimated coefficient on neighboring instutions measures the effect of an institutional improvement in all neighboring countries. Combining these two findings we thus find that institutions still rule but geography also matters in the sense that the

\footnotetext{
${ }^{10}$ Adding integration (openness) instrumented by the Frankel and Romer (1999) instrument does not change any of the results shown in our paper. Furthermore integration is, as in Rodrik et al. (2004), invariably insignificant. Results are available upon request.

${ }^{11}$ To arrive at the corresponding coefficients in Table 3 of Rodrik et al. (2004) for the geography (distance to the equator) and institutions (rule of law), our estimated coefficients should be multiplied by the standard deviation, 0.172 and 1.030 for geography and institutions respectively.
} 
geography of institutions (here, neighboring institutions) helps to explain income differences in our sample of 147 countries. In the remainder of this section we want to find out if this main result still holds for alternative measures of spatial institutions, after including regional and other fixed effects, for alternative country samples, and, recall section 2 , for specifications that include a different measures of $2^{\text {nd }}$ nature geography, namely a country's market potential or market access, among the set of explanatory variables.

\subsection{Robustness checks}

As a first robustness check, we estimated our 2SLS baseline model with spatial institutions while using alternative spatial measures. Recall that in the baseline model we use contiguity but for islands we use the nearest neighbor (determined on the basis of the distance between capital cities). Columns (2) and (3) in Table 4 indicate whether our results are sensitive to the definition of neighbor for the "island" countries in our sample (obviously, for these countries contiguity does not make sense) ${ }^{12}$. In column (2) the reference city, chosen to determine the nearest neighbor, is a country's main city instead of its capital city, and in column (3) an island is assigned two (nearest) neighbors instead of one. It is clear that the results do hardly change at all.

Table 4 Using alternative spatial measures

\begin{tabular}{|c|c|c|c|c|c|c|}
\hline \multicolumn{7}{|c|}{ Robustness 1: Different spatial measures } \\
\hline \multicolumn{7}{|c|}{ 2SLS, dependent variable: log GDP per capita in 1995 [Instrumented: Institutions (rule of law)] } \\
\hline & (1) Baseline & (2) & (3) & (4) & (5) & (6) \\
\hline & \multicolumn{3}{|c|}{ Contiguity (avg 2.9 neighbors) } & \multicolumn{3}{|c|}{ Nearest neighbor (capital city) area weighted } \\
\hline & capital city & main city & capital city (2) & 10 & 5 & (capital city) \\
\hline \multirow[t]{2}{*}{ Geography (distance equator) } & -2.45 & -2.46 & -2.32 & -2.68 & -2.51 & -1.96 \\
\hline & $(-2.13)$ & $(-2.14)$ & $(-2.35)$ & $(-3.11)$ & $(-2.82)$ & $(-1.93)$ \\
\hline \multirow[t]{2}{*}{ Institutions (rule of law) } & 0.92 & 0.93 & 1.11 & 1.15 & 1.14 & 1.09 \\
\hline & $(2.75)$ & $(2.78)$ & $(4.22)$ & $(5.70)$ & $(5.34)$ & $(4.03)$ \\
\hline \multirow[t]{2}{*}{ Neighboring Institutions (rule of law) } & 0.75 & 0.73 & 0.52 & 0.65 & 0.58 & 0.45 \\
\hline & $(2.69)$ & $(2.65)$ & (2.33) & $(4.41)$ & (3.58) & $(2.12)$ \\
\hline nr observations & 147 & 147 & 147 & 147 & 147 & 147 \\
\hline
\end{tabular}

Note: capital city (2), $3^{\text {rd }}$ column, means islands are contiguous to 2 nearest neighbors (instead of 1 ). $1^{\text {st }}$ stage results, as in Table 3 column (5) or (7). t-values in parentheses.

When we dismiss contiguity all together and define spatial institutions in terms of nearest neighbors for all 147 countries in our sample, columns (4) and (5) of Table 4 give the estimation results for various measures of nearest neighbor, where 10 or 5 refers to the

\footnotetext{
${ }^{12}$ Note that the "island" countries in our sample see top panel of Figure 2, are real islands as well as countries (like South Korea) that because of lack of data (North Korea is not in our sample) would have no neighbors in terms of contiguity.
} 
number of neighboring countries that we took into account in the definition of nearest neighbor. Invariably, distance to the n-nearest neighbors is measured by the distance between the corresponding capital cities. Finally, column (6) shows the results when using an areaweighted measure of contiguity in order to see whether giving more weight to larger neighbors affects the results. As can be seen, the results for the significance of institutions and neighboring institutions are not affected. Also, just as with our baseline results in section 4.1, $1^{\text {st }}$ nature geography is significant but has the wrong sign.

Another robustness check that is rather straightforward concerns the sample composition. Table 5 illustrates for 3 sub-samples of our overall sample of 147 countries whether the main results are sensitive to sample selection (again, only the $2^{\text {nd }}$ stage estimation results are shown). In order to avoid loss of information about the neighbors, the neighboring institutional variable in these regressions is based on the whole 147-sample. That is to say, fitted (neighboring) institutions are obtained from the first stage results using the 147-country sample, and next the $2^{\text {nd }}$ stage is done using a specific subsample. The basic message is that the conclusions with respect to our main variables of interest, institutions and neighboring institutions, are not affected. Note that when excluding Africa or the Western countries from the sample, the significance of neighboring institutions drops slightly compared to the baseline sample (to the $5.9 \%$ or the $4.9 \%$ level respectively), suggesting that it is the variance between Africa and the Western countries that contributes to the more significant results in the baseline sample (see also Easterly and Levine, 1998 for a similar finding).

\section{Table 5 Changing the sample size}

Robustness 2: sample

2SLS, dependent variable: log GDP per capita in 1995 [Instrumented: Institutions (rule of law)]

\begin{tabular}{|c|c|c|c|c|}
\hline & (1) Baseline & (2) non West & (3) no Africa & (3) no Islands \\
\hline \multirow[t]{2}{*}{ Geography (distance equator) } & -2.45 & -3.00 & -0.96 & -3.15 \\
\hline & $(-2.13)$ & $(-2.30)$ & $(-1.08)$ & $(-2.18)$ \\
\hline \multirow[t]{2}{*}{ Institutions (rule of law) } & 0.92 & 1.10 & 0.61 & 1.06 \\
\hline & $(2.75)$ & $(2.79)$ & $(2.58)$ & $(2.56)$ \\
\hline \multirow[t]{2}{*}{ Neighboring Institutions (rule of law) } & 0.75 & 0.61 & 0.45 & 0.81 \\
\hline & $(2.69)$ & $(1.89)$ & $(1.97)$ & $(2.45)$ \\
\hline nr observations & 147 & 124 & 118 & 98 \\
\hline
\end{tabular}

Notes: non West refers to the sample excluding all Western European countries, the USA, Canada, Australia and New Zealand. t-values in parentheses. $1^{\text {st }}$ stage results, as in Table 3 column (5) or (7). t-values in parentheses. 
By far the most important robustness check that we carried out, however, deals with the extension of our baseline model by adding additional controls that have been suggested in the literature. Since we are using Rodrik et al. (2004) as our benchmark, we based our selection of additional explanatory variables largely on the control variables used in that paper (Rodrik et al. (2004), Table 6, p. 148). More specifically, see our Table 6 below, we decided to add as controls 3 regional dummies, additional measures of $1^{\text {st }}$ nature geography and the identity of the (European) colonizer and religion.

Table 6 1st nature geography, main colonizer identity and religion as controls Robustness 3: regional dummies, extra geography, origin of colonizer, religion

\begin{tabular}{|c|c|c|c|c|c|c|c|c|}
\hline \multicolumn{9}{|c|}{ 2SLS, dependent variable: log GDP per capita in 1995 [Instrumented: Institutions (rule of law)] } \\
\hline & (1) Baseline & $(2)$ & (3) & (4) & $(5)$ & $(6)$ & $(7)$ & $(8)$ \\
\hline \multirow[t]{2}{*}{ Geography (distance equator) } & -2.45 & -0.45 & -1.52 & 0.18 & -1.75 & -2.03 & -0.33 & -0.48 \\
\hline & $(-2.13)$ & $(-0.64)$ & $(-1.54)$ & $(0.27)$ & $(-1.29)$ & $(-1.65)$ & $(-0.40)$ & $(-0.65)$ \\
\hline \multirow[t]{2}{*}{ Institutions (rule of law) } & 0.92 & 0.72 & 0.99 & 0.69 & 1.04 & 0.66 & 0.80 & 0.64 \\
\hline & $(2.75)$ & $(6.51)$ & (3.69) & $(6.49)$ & $(2.86)$ & $(1.85)$ & $(5.09)$ & $(4.46)$ \\
\hline \multirow[t]{2}{*}{ Neighboring Institutions (rule of law) } & 0.75 & 0.35 & 0.43 & 0.28 & 0.56 & 0.58 & 0.23 & 0.30 \\
\hline & $(2.69)$ & $(2.60)$ & $(2.35)$ & $(2.66)$ & $(2.66)$ & $(2.37)$ & $(2.19)$ & $(2.76)$ \\
\hline \multicolumn{9}{|l|}{ Regional dummies } \\
\hline \multirow[t]{2}{*}{ Sub-Saharan Africa } & - & -0.36 & - & -0.21 & - & - & -0.41 & 0.15 \\
\hline & - & $(-1.95)$ & - & $(-1.20)$ & - & - & $(-1.98)$ & $(0.52)$ \\
\hline \multirow[t]{2}{*}{ Latin America + Caribean } & - & 0.36 & - & 0.36 & - & - & 0.22 & 0.33 \\
\hline & - & $(2.44)$ & - & $(2.51)$ & - & - & $(0.95)$ & $(1.41)$ \\
\hline \multirow[t]{2}{*}{ East-South-East Asia } & - & 0.09 & - & 0.16 & - & - & 0.18 & 0.20 \\
\hline & - & $(0.51)$ & - & $(1.01)$ & - & - & $(0.97)$ & $(1.21)$ \\
\hline \multicolumn{9}{|l|}{ other Geography } \\
\hline \multirow[t]{2}{*}{ landlocked } & - & - & -0.52 & -0.49 & - & - & -0.42 & -0.46 \\
\hline & - & - & $(-3.64)$ & $(-3.73)$ & - & - & $(-3.29)$ & $(-3.71)$ \\
\hline \multirow[t]{2}{*}{ island } & - & - & -0.03 & -0.04 & - & - & 0.11 & -0.18 \\
\hline & - & - & $(-0.18)$ & $(-0.39)$ & - & - & $(0.76)$ & $(-1.28)$ \\
\hline \multirow[t]{2}{*}{ area } & - & - & 0.00 & -0.03 & - & - & -0.02 & -0.02 \\
\hline & - & - & $(0.05)$ & $(-1.14)$ & - & - & $(-0.77)$ & $(-0.55)$ \\
\hline \multirow[t]{2}{*}{ malaria (MALFAL) } & - & - & - & - & - & -0.90 & - & -1.33 \\
\hline & - & - & - & - & - & $(-2.78)$ & - & $(-1.50)$ \\
\hline \multirow[t]{2}{*}{$\%$ speaking english } & - & - & - & - & -0.44 & - & -0.48 & - \\
\hline & - & - & - & - & $(-1.09)$ & - & $(-1.75)$ & - \\
\hline Indentity European colonizer & no & no & no & no & yes & no & yes & no \\
\hline \% Religion & no & no & no & no & yes & no & yes & no \\
\hline
\end{tabular}

\section{1st stage}

Instrumented variable:

Institutions Institutions Institutions

\begin{tabular}{|c|c|c|c|c|c|c|c|c|}
\hline Instrumented varıable: & Institutions & Institutions & Institutions & Institutions & Institutions & Institutions & Institutions & Institutions \\
\hline \multirow[t]{2}{*}{$\%$ speaking european language } & 0.70 & 1.27 & 0.62 & 1.30 & 0.74 & 0.62 & 1.06 & 1.27 \\
\hline & $(5.48)$ & (7.69) & $(4.56)$ & $(6.85)$ & $(4.24)$ & (3.91) & (5.73) & $(6.25)$ \\
\hline \multirow[t]{2}{*}{ Geography (distance equator) } & 4.01 & 3.40 & 4.14 & 3.54 & 3.41 & 3.98 & 3.44 & 3.22 \\
\hline & $(12.72)$ & (6.98) & $(14.91)$ & $(7.55)$ & (7.55) & (11.18) & $(5.45)$ & $(6.41)$ \\
\hline nr observations & 147 & 147 & 147 & 147 & 147 & 130 & 147 & 130 \\
\hline
\end{tabular}

Notes: The $1^{\text {st }}$ stage results only show the estimated coefficients on the instrument (\% speaking a European language) and geography. The $1^{\text {st }}$ stage coefficients of the other exogenous controls are not shown in order to save space. Also the $1^{\text {st }}$ stage for the malaria variable, instrumented by a measure of malaria ecology, is not shown here. $t$-values in parentheses. 
The reason to add controls like the regional dummies and the other geography variables is that we set out to estimate spatial dependence between countries (via our neighboring institutions variable) but in Tables 3-5 it could be that the found relevance of spatial dependence is simply due to spatial heterogeneity because of omitted variables that are regional in nature like the regional dummies and the landlocked or malaria variable. Of these additional control variables, three variables in particular have been subject of discussion in the literature because of their alleged importance: the Sub-Saharan Africa dummy, the landlocked variable, and malaria (see Appendix A for definitions of all included controls).

The estimation results (both the $1^{\text {st }}$ and $2^{\text {nd }}$ stage results are shown in Table 6) lead to the following conclusions:

-First, most importantly, our main results carry through. In all specifications, neighboring institutions are significant (and $1^{\text {st }}$ nature geography only has an indirect impact on gdp per capita).

-Second, when comparing our results to the corresponding results in Rodrik et al. (2004), it is clear that the coefficient on own-country institutions is much lower in our case. Whereas we find a coefficient of approx. 0.7-0.9, in Rodrik et al. (2004) the corresponding coefficient is in the range of approximately 1.5-2.5.

-Third, of the additional controls the landlocked variable seems to be most important in the sense that it is significant in all of the specifications shown in Table 6 . This is not in line with the findings in Rodrik, et al. (2004), where the landlocked variable is not significant. The fact that we do find a significantly negative, direct, effect of being landlocked is probably due to the larger sample that we use. 13 of the 68 countries that our sample is larger than the baseline sample in Rodrik et al. (2004) are actually landlocked (e.g. Malawi, Nepal, Mongolia and Zimbabwe, see also Figure 3), allowing us to better pinpoint the effect of being landlocked. The Sub-Saharan Africa dummy is not significant once landlocked and/or malaria are also added as a controls, see column (4) and (8). Also of interest is the finding, in line with Rodrik et al. (2004), that the malaria variable is significant when included on its own (column (6)) but this is no longer the case when the regional dummies are added as controls.

\subsection{New Economic Geography and Spatial GDP}

In section 2 we referred to the new economic geography literature where income differences between countries are explained by the spatial income dependency between countries. It might 
therefore be argued that the real importance in terms of including $2^{\text {nd }}$ nature geography is not so much spatial institutions but spatial income.

Table 7 Spatial GDP and Spatial Institutions

Robustness 4: adding Market Access (MA), i.e. spatial GDP

2SLS, dependent variable: log GDP per capita in 1995

\begin{tabular}{|c|c|c|c|c|c|c|c|c|}
\hline \multirow{3}{*}{ Geography (distance equator) } & \multirow{2}{*}{$\begin{array}{c}\text { (1) Baseline } \\
-2.45\end{array}$} & (2) MA & \multicolumn{2}{|c|}{ (3) MA + Institutions } & \multicolumn{2}{|c|}{ (4) MA + Neigh. Inst. } & \multicolumn{2}{|c|}{ (5) + extra controls } \\
\hline & & - & \multicolumn{2}{|c|}{0.10} & \multicolumn{2}{|c|}{-0.62} & \multicolumn{2}{|c|}{0.04} \\
\hline & $(-2.13)$ & - & \multicolumn{2}{|l|}{$(0.11)$} & \multicolumn{2}{|c|}{$(-0.60)$} & \multicolumn{2}{|c|}{$(0.05)$} \\
\hline \multirow[t]{2}{*}{ Institutions (rule of law) } & 0.92 & - & \multicolumn{2}{|l|}{1.23} & \multicolumn{2}{|l|}{0.90} & \multicolumn{2}{|c|}{0.69} \\
\hline & $(2.75)$ & - & \multicolumn{2}{|c|}{$(7.98)$} & \multicolumn{2}{|c|}{$(4.55)$} & \multicolumn{2}{|c|}{$(6.37)$} \\
\hline \multirow[t]{2}{*}{ Neighboring Institutions (rule of law) } & 0.75 & - & \multicolumn{2}{|c|}{-} & \multicolumn{2}{|c|}{0.54} & \multicolumn{2}{|c|}{0.30} \\
\hline & $(2.69)$ & - & \multicolumn{2}{|l|}{-} & \multicolumn{2}{|c|}{$(2.87)$} & \multicolumn{2}{|c|}{$(2.72)$} \\
\hline \multirow[t]{2}{*}{ Market Access (Spatial GDP) } & - & 0.84 & -0.37 & & -0.41 & & 0.03 & \\
\hline & - & $(5.38)$ & $(-2.10)$ & & $(-1.97$ & & $(0.13$ & \\
\hline Regional dummies & & & & & & & & \\
\hline Sub-Saharan Africa & - & - & - & & - & & -0.10 & \\
\hline & - & - & - & & - & & $(-0.98$ & \\
\hline Latin America + Caribean & - & - & - & & - & & 0.38 & \\
\hline & - & - & - & & - & & $(1.94$ & \\
\hline East-South-East Asia & - & - & - & & - & & 0.13 & \\
\hline & - & - & - & & - & & $(0.67$ & \\
\hline other Geography & & & & & & & & \\
\hline landlocked & - & - & - & & - & & $-0.4 \mathrm{C}$ & \\
\hline & - & - & - & & - & & $(-3.4 \varepsilon$ & \\
\hline island & - & - & - & & - & & -0.04 & \\
\hline & - & - & - & & - & & $(-0.28$ & \\
\hline area & - & - & - & & - & & -0.03 & \\
\hline & - & - & - & & - & & $(-1.12$ & \\
\hline & & & stage & & & & & \\
\hline Instrumented variable & Institutions & MA & Institutions & MA & Institutions & MA & Institutions & MA \\
\hline$\%$ speaking european language & 0.70 & - & 1.04 & -0.06 & 1.04 & -0.06 & 1.27 & -0.08 \\
\hline & $(5.48)$ & - & $(5.75)$ & $(-0.65)$ & $(5.75)$ & $(-0.65)$ & $(6.30)$ & $(-0.92)$ \\
\hline Geography (distance equator) & 4.01 & - & 3.18 & 1.62 & 3.18 & 1.62 & 3.66 & 1.25 \\
\hline & $(12.72)$ & - & $(6.24)$ & $(5.83)$ & $(6.24)$ & $(5.83)$ & $(7.28)$ & $(4.48)$ \\
\hline Distance New York & - & 0.20 & 0.16 & 0.24 & 0.16 & 0.24 & -0.04 & 0.23 \\
\hline & - & $(2.08)$ & $(1.04)$ & $(2.88)$ & $(1.04)$ & $(2.88)$ & $(-0.36)$ & $(2.96)$ \\
\hline Distance Brussels & - & -0.43 & -0.16 & -0.23 & -0.16 & -0.23 & 0.04 & -0.23 \\
\hline & - & $(-13.00)$ & $(-2.09)$ & $(-6.28)$ & $(-2.09)$ & $(-6.28)$ & $(0.49)$ & $(-6.04)$ \\
\hline Distance Tokyo & - & -0.48 & -0.37 & -0.31 & -0.37 & -0.31 & 0.09 & -0.06 \\
\hline & - & $(-4.03)$ & $(-3.18)$ & $(-2.97)$ & $(-3.18)$ & $(-2.97)$ & $(0.35)$ & $(-0.74)$ \\
\hline nr observations & 147 & 147 & 147 & & 147 & & 147 & \\
\hline
\end{tabular}

Notes: The $1^{\text {st }}$ stage results only show the estimated coefficients on the instrument (\% speaking a European language) and geography. The $1^{\text {st }}$ stage coefficients of the other exogenous controls are not shown in order to save some space. Instrument validity for the distance instruments is rejected when including only Market Access (Hansen J-statistic: 22.29 [p-value: 0.00]) but accepted when including also geography and (neighboring) institutions (Hansen J-statistic: 2.70 [p-value: 0.26]). t-values in parentheses. 
As a $1^{\text {st }}$ pass (and certainly not more than that), Table 7 therefore adds market access (MA) to our set of explanatory variables where MA of country $\mathrm{j}$ is measured as $M A_{j}=\sum_{i} G D P_{i} / D_{i j}$ with $\mathrm{D}_{\mathrm{ij}}=$ great circle distance between capital cities of countries $\mathrm{i}$ and $\mathrm{j}$. Our measure of market access is thus basically a simple market potential function. Redding and Venables (2004) construct a similar MA measure and more sophisticated market access measures and invariably find that market access is very significant in explaining cross-country differences in gdp per capita: a better market access implies a higher gdp per capita. This finding also holds when they control for the role of institutions.

The first column in Table 7 again shows our baseline results and the second column illustrates that, when looked upon in isolation, market access (MA) has the expected significant positive effect on gdp per capita. Following Redding and Venables (2004), MA is instrumented by the log distance to three economic centers (New York, Brussels and Tokyo). When we then add own-country institutions, see column (3), MA has the wrong sign. This also holds when neighboring institutions are added, see column (4). More importantly, the addition of the market access variable does not alter our main finding that institutions matter and also that neighboring institutions play a role. The last column of Table 7 confirms this. After controlling for regional and other fixed geography effects, where the landlocked dummy again is significant, (spatial) institutions remain significant and market access is now insignificant (but positive).

As to the question why our findings differ from those of Redding and Venables (2004), a number of possibilities arise. They do for instance not instrument institutions and only look at own country institutions, also their country sample is somewhat smaller (101 countries) to the effect that their sample does not include a number of (African) countries with bad institutions. Moreover, the focus of their analysis is different. Even though they report estimation results for the specification with our simple market access variable and institutions (footnote 15 , p.65), the bulk of their paper and estimation results deals with market access measures that are better grounded in NEG theory. An interesting question for future research would be to look more closely at which kind of spatial interdependencies matter most in explaining income differences between countries. 


\subsection{Indirect Channels of Influence}

For the spatial variable that is at the center of our analysis, neighboring institutions, one wants to learn more about the channels along which the quality of institutions has a good or bad impact on neighboring countries. Following suggestions offered by for example Easterly and Levine, 1998, Murdoch and Sandler, 2002 and Ades and Chua, 1997 (mentioned more explicitly in Section 2 of this paper), Table 8 suggests, by way of first illustration, some possible channels of influence.

\section{Table 8 Possible channels of influence for neighboring institutions}

\begin{tabular}{|c|c|c|c|}
\hline Variable & $\begin{array}{c}\text { Correlation with } \\
\text { neighboring institutions }\end{array}$ & Variable & $\begin{array}{c}\text { Correlation with } \\
\text { neighboring institutions }\end{array}$ \\
\hline \multirow[t]{2}{*}{ assasinations } & $-0.09[0.37]$ & $\begin{array}{l}\text { prima facie refugees } \\
\text { (arrivals on a group }\end{array}$ & $-0.18[0.03]$ \\
\hline & 109 & basis) & 147 \\
\hline \multirow[t]{2}{*}{ revolutions/coups } & $-0.31[0.00]$ & refugees per GDP & $-0.14[0.11]$ \\
\hline & 129 & & 128 \\
\hline \multirow[t]{2}{*}{ political instability } & $-0.25[0.01]$ & $\%$ arms in total imports & $-0.07[0.43]$ \\
\hline & 109 & & 132 \\
\hline \multirow[t]{2}{*}{ external war } & $-0.31[0.00]$ & $\%$ workforce in military & $0.12[0.18]$ \\
\hline & 147 & & 131 \\
\hline$\%$ government budget & $-0.26[0.01]$ & & \\
\hline spent on military & 97 & & \\
\hline
\end{tabular}

The general message that Table 8 conveys is that armed conflicts and political turmoil are possible channels by which a country might suffer in terms of its gdp per capita because of the low quality of institutions in its neighboring countries, thus confirming some of the findings in Easterly and Levine, 1998, Ades and Cha, 1997 or Murdoch and Sandler, 2002. Similarly, one can envision how inferior institutions in other countries, corrected for distance, negatively affect trade and factor mobility. On a more general level, the question why and how instrumented spatial institutions and also instrumented own-country institutions have an impact on economic development is not answered by the IV-framework on which our analysis is based. This is aptly summarized by Rodrik et al. (2004, pp. 153-154) where they state that even a powerful instrument is a long cry from a "full theory of cause and effect".

\section{Summary and Conclusions}

To explain cross-country income differences, economic research has recently focused on the so-called deep determinants of economic development, notably institutions and geography. This paper sheds a different light on these determinants. We use spatial econometrics to 
analyse the geography of institutions. Based on a sample of 147 countries, we show that is not so much a country's absolute location, in terms of for instance its climate, but its relative location in terms of its institutions that matters for gdp per capita. Apart from a country's own institutions, institutions in neighboring countries turn out to be relevant as well. This finding is robust to various alternative specifications in terms of spatial measures, sample size, and additional controls including spatial GDP.

Set against the seminal paper by Rodrik, Subramanian, and Trebbi (2004) we conclude that:

- 1 st nature or fixed geography (i.e. distance to the equator) only has an indirect impact on gdp per capita in the baseline specification; it is only through institutions (here, rule of law) that this version of geography matters.

- Institutions are invariably significant in explaining cross-country differences in gdp per capita; that is the exogenous variation in institutions as captured by our instruments is always significant.

These two conclusions are in line with Rodrik et al (2004), but by using spatial econometrics we also find that

- The geography of institutions matters as well. A country's gdp per capita does not only depend on own-country institutions but on the quality of institutions in its neighboring countries as well. This is our main result and it shows that economic development does not take place in isolation. Moreover, our estimation results indicate that by excluding the spatial feature of institutions, studies like Rodrik et al (2004) probably overestimate the relevance of own-country institutions and policies.

- Moreover, of the control variables included the landlocked variable is significant in all specifications. This suggest that $1^{\text {st }}$ nature geography also plays a role in explaining world income differences, as countries without direct access to the sea (and thus the world export markets) have a substantially lower level of gdp per capita.

Given the importance that is nowadays attached to good governance by domestic as well as international policy makers like the IMF or the World Bank, a policy implication of our analysis is that economic development is not only stimulated by improved own-country institutions but also by better institutions across the region. Not only the extent and the type of institutional change matter, its effectiveness also depends on where it is implemented. In fact, good institutions may only be of limited use if a country continues to be surrounded by 
neighbors with very poor institutions. This illustrates the relevance of regional development policies; of concerted efforts to raise institutional standards in a group of neighboring countries at the same time. As to the future research that our analysis may give rise to, two directions come to mind. The first one is to get a better understanding of the transmission channels through which neighboring institutions matter (see Table 8 above). The second one is to look more closely at alternative measures of spatial interdependency. Instead of focusing only on physical distance, one could think of other reasons (e.g. common language, religion or history, political or economic alliances) as to why other countries might matter for one's prosperity (see also Simmons and Elkins, 2004). In addition to alternative measures of space (physical as opposed to for instance mental or cultural distance), a related avenue for future research would be to improve our understanding of the relative importance of the different variables through which $2^{\text {nd }}$ geography matters (e.g. spatial institutions vs. spatial gdp). 


\section{References}

Acemoglu, D., 2005, Constitutions, Politics, and Economics: A Review Essay on Persson and Tabellini's "The Economic Effects of Constitutions", Journal of Economic Literature, XLIII, pp.1025-1048.

Acemoglu, D., S. Johnson and J.A. Robinson, 2001, The Colonial Origins of Comparative Development: An Empirical Investigation, American Economic Review, Vol 91(5), pp.1369-1401.

Ades, A. and H.B. Chua, 1997, Thy Neighbor's Curse: Regional Instability and Economic Growth, Journal of Economic Growth, 2, pp.279-304.

Alcalá, F. and A. Ciccone, 2004, Trade and Productivity, Quarterly Journal of Economics, 119, pp.613-646.

Anselin, L., 1988, Spatial Econometrics: Methods and Models, London, Kluwer.

Crafts, N. and A.J. Venables, 2001, Globalization in History: A Geographical Perspective, CEPR Discussion Paper, 3079, London.

Easterly, W. and R. Levine, 1998, Troubles with the Neighbours: Africa's Problem, Africa's Opportunity, Journal of African Economics, Vol. 7 (1), pp.120-142

Easterly W. and R. Levine, 2003, Tropics, Germs, and Crops: How Endowments Influence Economic Development, Journal of Monetary Economics, 50, pp. 3-40.

Fujita, M., P. Krugman, and A.J. Venables, 1999, The Spatial Economy, MIT Press.

Glaeser, E, R. LaPorta, F. Lopes-de-Silanes, and A. Shleifer, 2004, Do Institutions Cause Growth?, Journal of Economic Growth, 9, pp. 271-303.

Hall, R. and C.I. Jones, 1999, Why Do Some Countries Produce So Much More Output Per Worker than Others?, Quarterly Journal of Economics, 114, pp. 83-116.

Krugman., P., 1993, First Nature, Second Nature, and Metropolitan Location, Journal of Regional Science, 33, pp. 129-144.

McArthur, J.W. and J.D. Sachs, 2001, Institutions and Geography: Comment on Acemoglu, Johnson and Robinson (2000), NBER Working Paper, no. 8114, Cambridge Mass.

Murdoch, J.C. and T. Sandler, 2002, Economic Growth, Civil Wars and Spatial Spillovers, Journal of Conflict Resolution, 46(1), pp. 91-110.

Rajan, R.G. and L. Zingales, 2006, The Persistence of Underdevelopment: Institutions, Human Capital or Constituencies, NBER Working Paper, no. 12093, Cambridge Mass.

Redding, S. and A.J. Venables, 2004, Economic Geography and International Inequality, Journal of International Economics, 62(1), pp. 53-82.

Rodrik, D, A. Subramanian, and F. Trebbi, 2004, Institutions Rule, The Primacy of Institutions Over Geography and Integration in Economic Development, Journal of Economic Growth, 9, pp. 131-165.

Sachs, J.D., 2003, Institutions Don't Rule: Direct Effects of Geography on Per Capita Income, NBER Working Paper, no. 9490, Cambridge Mass.

Simmons, B.A. and Z. Elkins, 2004, The Globalization of Liberalization: Policy Diffusion in the International Political Economy, American Political Science Review, 98(1), pp. 171189. 


\section{Appendix A: Data, definitions and sources}

\section{GDP per capita in 1995}

Purchasing Power Parity basis, from World Bank, World Development Indicators, 2003. For 11 countries with no data provided by the World Bank, we used the CIA World Factbook, 1995 or 1996

Institutions

Rule of Law index. Refers to 2000 and approximates for 1990's institutions, from Kaufmann et al. (2005):

http://www.worldbank.org/wbi/governance/govdata/index.html.

Geography

Distance from the equator measured as abs(latitude)/90, from Hall and Jones, 1999:

http://emlab.berkeley.edu/users/chad/HallJones400.asc.

$\%$ speaking European language

$\%$ of the population speaking one of the major languages of Western Europe at birth, i.e. English, French, Spanish,

Portuguese or German. From Hall and Jones, 1999: http://emlab.berkeley.edu/users/chad/HallJones400.asc.

$\%$ speaking English

$\%$ of the population speaking English at birth, from Hall and Jones, 1999:

http://emlab.berkeley.edu/users/chad/HallJones400.asc.

Sub-Saharan Africa

Dummy variable taking value 1 if a country belongs to Sub-Saharan Africa and 0 otherwise.

Latin America and the Caribbean

Dummy variable taking value 1 if a country belongs to Latin America or the Caribbean and 0 otherwise.

East-South-East Asia

Dummy variable taking value 1 if a country belongs to East-South-East Asia and 0 otherwise.

Landlocked

Dummy variable taking value 1 if a country has no direct access to the sea and 0 otherwise.

Island

Dummy variable taking value 1 if a country is an island and 0 otherwise.

Area

Land area (in square kilometers), from CEPII: http://www.cepii.fr/distance/geo_cepii.xls.

Identity Main European Colonizer

Dummy variables taking the value 1 if a country's main colonizer was one of the following Western European countries:

Great Britain, France, Spain, Portugal, The Netherlands, Belgium or Germany and 0 otherwise. From CEPII:

http://www.cepii.fr/distance/geo_cepii.xls.

Religion

Variables measuring the \% of the population that belonged to one of the following religions: Buddhism, Hinduism,

Catholicism, Islam and Protestantism. From Barro, 1996 (for 12 countries we used the CIA World Factbook).

Distance to Economic Center

Variables measuring the distance of a country's capital city to one of the following economic centres: New York (USA),

Tokyo (Japan) and Brussels (EU). From CEPII: http://www.cepii.fr/distance/geo_cepii.xls.

GDP in 1995

Purchasing Power Parity basis, from World Bank, World Development Indicators, 2003. For 11 countries with no data provided by the World Bank, we used the CIA World Factbook, 1995 or 1996

Relative Geography

Contiguity: A matrix indicating for all country pairs if the two countries are contiguous, 1 , or not, 0 . From

http://www.cepii.fr/distance/geo_cepii.xls.

Distances: A matrix containing the distance between capital (or main) cities for all country pairs. From

http://www.cepii.fr/distance/geo_cepii.xls.

Assasinations

Average number of assasinations per million population over the period, 1960-1990. From Barro and Lee, 1995.

Revolutions/coups

Average number of revolutions and coups over the period 1960-1990. From Barro and Lee, 1995.

Political instability

From Knack and Keefer, 1995.

External war

Dummy variable taking value 1 if a country was involved in at least one external war during the period 1960-1990 and 0

otherwise. From Barro and Lee, 1995.

$\%$ government budget spent on the military

Average 1989-1999, from World Bank, World Development Indicators, 2003.

Prima facie refugees

Number of refugees granted refugee status on a prima facie/group basis, average 1994-2000. From UNHCR, Statistical

Yearbook 2003: http://www.unhcr.org/cgi-bin/texis/vtx/statistics/.

Refugees per GDP

Total number of refugees and person of concern to UNHCR divided by the Gross Domestic Product, average 1994-2000.

From UNHCR, Statistical Yearbook 2003: http://www.unhcr.org/cgi-bin/texis/vtx/statistics/.

$\%$ of arms in total imports

Average 1989-1999, from World Bank, World Development Indicators, 2003.

\% workforce in the military

Average 1989-1999, from World Bank, World Development Indicators, 2003. 


\section{Malaria (MALFAL)}

The percentage of the population at risk of contracting falciparum malaria. From The Earth Institute at Colombia University: http://www.earthinstitute.columbia.edu/about/director/malaria/index.html\#datasets.

Malaria ecology

An ecologically-based spatial index of the stability of malaria transmission. From The Earth Institute: http://www.earthinstitute.columbia.edu/about/director/malaria/index.html\#datasets.

\section{Appendix B The validity of \% speaking European language as an instrument}

As mentioned in the text, Rodrik et al. (2004) decide to use 79 countries as their baseline sample. The reason for this is that:

"We ... prefer this sample to the 137-country sample because settler mortality appears to be a superior instrument to those used in the 137-country sample (ENGFRAC and EURFRAC).... the instruments for the IV regressions in the 137-country sample fail to pass the over-identification tests ..." (Rodrik et al, 2004, p.143).

This failure of the language instruments to pass the over-identification test also applies to our 147 country sample. Failure of these two instruments (or any instruments in general) to pass these tests sheds considerable doubt on the resulting $2^{\text {nd }}$ stage estimates when making use of these instruments. However not being able to use the 147 country sample would leave us with considerable problems (see main text) when trying to estimate the effect of neighboring institutions. The solution to the problem that we have resorted to is to use the variable "\% of the population speaking a European language" as our only instrument. We think we have good reasons to believe in the validity of this instrument. Our argument goes as follows: 1. Failing to pass the overidentification test does not necessarily mean that both instruments are invalid. What is tested is if one instrument is valid given that the other instrument is valid. Rejecting the null hypothesis may as well be interpreted as evidence that only one of the two instruments is correlated with the $2^{\text {nd }}$ stage error term.

2. How to establish if this is the case? To do this we have come up with the following estimation strategy. Ideally we would have liked to have a third (and valid) instrument in case of our 147 country sample so that we can test the validity of each of the language instruments separately using the over-identification test. We have to admit that we do not have such an instrument in our 147 country sample case, however in case of Rodrik et al.'s (2004) baseline sample of 79 countries we do have such an instrument, namely the Acemoglu et al. (2001) measure of settler mortality. So by restricting ourselves to the 79 country sample, we have performed 2SLS estimation using any subset of the three instruments we have at hand in that case.

3. Table A1 shows the results. The first three columns show the $1^{\text {st }}$ and $2^{\text {nd }}$ stage results when using only one of the available instruments in the $1^{\text {st }}$ stage. In that case overidentification tests, i.e. tests to establish the uncorrelatedness of the instrument with the residuals in the $2^{\text {nd }}$ stage, cannot be preformed and the only way to establish whether or not an instrument is valid is to look at the F-statistic on the instrument in the $1^{\text {st }}$ stage, i.e. the instrument has to be correlated to the institutional quality measure. All three potential instruments pass this simple test. So (econometrically speaking) there is no reason to write off any of the instruments at this stage (to believe in any of the instruments in this case, relies solely on the 'story' behind the instrument). 
Table A1 Results on the instrument validity

\begin{tabular}{|c|c|c|c|c|c|c|c|}
\hline \multicolumn{8}{|c|}{ Dependent variable: log GDP per capita in 1995} \\
\hline & 2SLS & $2 S L S$ & $2 S L S$ & $2 S L S$ & $2 S L S$ & $2 S L S$ & 2SLS \\
\hline \multirow[t]{2}{*}{ Geography (distance equator) } & $-1,43$ & $-2,25$ & 0,80 & 0,16 & $-0,41$ & $-1,79$ & $-0,31$ \\
\hline & $(-0,94)$ & $(-1,35)$ & $(1,11)$ & $(0,20)$ & $(-0,05)$ & $(-1,26)$ & $(-0,34)$ \\
\hline \multirow[t]{2}{*}{ Institutions (rule of law) } & 1,52 & 1,74 & 0,93 & 1,10 & 1,15 & 1,61 & 1,22 \\
\hline & $(5,10)$ & $(4,93)$ & $(9,83)$ & $(9,62)$ & $(8,83)$ & $(6,27)$ & $(8,68)$ \\
\hline Hansen $\mathrm{J}$ test statistic & - & - & - & 10,280 & 6,633 & 0,297 & 12,018 \\
\hline$[p$-value] & - & - & - & {$[0,001]$} & {$[0,010]$} & {$[0,586]$} & {$[0,003]$} \\
\hline Difference J statistic & & & & & & & 11,721 \\
\hline \multirow[t]{2}{*}{ [p-value] } & & & & & & & {$[0,000]$} \\
\hline & \multicolumn{4}{|c|}{ 1st stage } & & & \\
\hline Instrumented variable & Institutions & Institutions & Institutions & Institutions & Institutions & Institutions & Institutions \\
\hline \multirow[t]{2}{*}{ log settler mortality } & $-0,31$ & - & - & - & $-0,24$ & $-0,26$ & $-0,23$ \\
\hline & $(-3,41)$ & - & - & - & $(-2,57)$ & $(-2,57)$ & $(-2,32)$ \\
\hline \multirow[t]{2}{*}{ \% speaking European language } & - & 0,77 & - & 0,30 & - & 0,59 & 0,20 \\
\hline & - & $(4,02)$ & - & $(1,63)$ & - & $(2,91)$ & $(0,96)$ \\
\hline \multirow[t]{2}{*}{ \% speaking English } & - & - & 1,47 & 1,23 & 1,25 & - & 1,11 \\
\hline & - & - & $(5,91)$ & $(4,29)$ & $(5,10)$ & - & $(4,06)$ \\
\hline \multirow[t]{2}{*}{ Geography (distance equator) } & 2,28 & 3,08 & 2,88 & 2,74 & 1,86 & 1,99 & 1,81 \\
\hline & $(2,60)$ & $(4,10)$ & $(4,12)$ & $(3,98)$ & $(2,17)$ & $(2,31)$ & $(2,14)$ \\
\hline F-statistic (instruments) & 11,66 & 16,18 & 34,90 & 18,51 & 23,23 & 12,98 & 16,62 \\
\hline Partial R-square & 0,19 & 0,16 & 0,29 & 0,30 & 0,39 & 0,28 & 0,40 \\
\hline $\mathrm{nr}$ observations & 79 & 79 & 79 & 79 & 79 & 79 & 79 \\
\hline
\end{tabular}

Note: Our sample of 79 differs from Rodrik et al.'s (2004) baseline sample in one aspect. Our sample does not include Vietnam because of the unavailability of the language variables, whereas Rodrik et al. (2004) exclude the Central African Republic from their baseline sample due to data unavailability reasons. When using the whole 147 country sample when settler mortality is not included as instrument, results are very similar to the 79 country sample. $t$-values in parentheses.

Next, columns 4-6 show the results when using a combination of two of the three instruments in the $1^{\text {st }}$ stage. Column 4 confirms the finding by Rodrik et al. (2004) in case of their 137 country sample and our finding in case of our 147 country sample: when including both language instruments the overidentification tests are not passed. This also holds when including settler mortality and \% speaking English as instruments (column 5). However when including settler mortality and \% speaking a European language (column 6) the overidentification test is passed with flying collars ( $p$-value 0.586$)^{13}$. As we have noted above failing to pass the overidentifaction test can be interpreted as telling you that at least one of the instruments is not appropriate. We take the fact that the overidentification test is passed when including both settler mortality and \% population speaking a European language, but not so when any of these two are included in combination with \% population speaking English, as evidence that this latter instrument is invalid whereas there is no evidence to

\footnotetext{
${ }^{13}$ Also note that the F-statistic on the instruments in the $1^{\text {st }}$ stage is always significant.
} 
believe that \% population speaking a European language is not a good instrument. ${ }^{14}$ Column 6 confirms this finding, as when including all three instruments, the overidentification test is again not passed. Given the result in column 5 we can also explicitly test for the validity of $\%$ population speaking English by calculating the difference in the J-statistic between column 6 and column 5 and comparing this to the $\chi(1)$ distribution. This results in rejecting the validity of \% population speaking English. Note also that the estimated $2^{\text {nd }}$ stage coefficient on the institutional quality measure is always within one standard deviation when using either only settler mortality, only \% speaking a European language or both of them as instruments, whereas the coefficient drops substantially when including also \% speaking English.

Combining the above-presented evidence and the need to have an as large as possible sample for our purpose of estimating the effect of $2^{\text {nd }}$ nature geography in the form of neighboring institutions (see main text), we have decided to use \% population speaking a European language as instrument ${ }^{15}$ in all of our 147 country regressions presented in the main text.

\section{Appendix C: 2SLS when estimating the effect of neighboring institutions}

The question whether or not to instrument neighboring institutions boils down to whether or not this measure can be expected to be correlated to the error term, see (5). As mentioned in the main text there are three main reasons why this could be the case, and here we will briefly comment on each of these.

\section{Reverse causality}

Can we expect that neighboring institutions are also directly influenced by one's own level of GDP per capita, i.e. Inst $_{i}=\varsigma y_{i}+v_{i}, \quad \varsigma \neq 0$ ? If this would be the case the need to instrument would immediately be established. However a direct effect of one's own level of GDP per capita on the institutions in one's neighboring countries may not be that convincing, although not unthinkable either. Still even if this 'direct' form of reverse causality would not be an issue, it is still true that it is likely that one's own level of GDP per capita affects the institutional quality in one's own country (one of the reasons to instrument own institutions),

$$
\text { Inst }_{i}=\varsigma y_{i}+v_{i}, \quad \varsigma \neq 0
$$

If true, this will result in a correlation between neighboring countries' institutions and the error term $\varepsilon$, establishing the need for instrumentation of neighboring institutions. To show this rewrite neighboring institutions in structural form using (AC1) and (2-ii), to get:

$$
\text { Wnst }_{i}=\left(1-\frac{\varsigma \lambda}{1-\varsigma \gamma} W\right)^{-1} W \frac{\varsigma \gamma}{1-\varsigma \gamma}\left(\alpha+\beta G e o_{i}+\varepsilon_{i}\right)+\frac{1}{1-\varsigma \gamma} W \eta_{i}
$$

By which we can see, after first noting that we can rewrite the inverse matrix in (AC2) as

$$
\left(1-\frac{\varsigma \lambda}{1-\varsigma \gamma} W\right)^{-1}=I+\left(\frac{\varsigma \lambda}{1-\varsigma \gamma}\right) W+\left(\frac{\varsigma \lambda}{1-\varsigma \gamma}\right)^{2} W^{2}+\ldots
$$

and remembering the assumption of exogeneity of the geography measure, Geo, that the measure of neighboring institutions will be correlated to the $2^{\text {nd }}$ stage error term $\varepsilon$ if $^{16}$,

\footnotetext{
${ }^{14}$ Note also that when one takes the validity of settler mortality as instrument for granted (as Rodrik et al. (2004) for example do), the results of the Hansen J-test when including both settler mortality and \% speaking a European language can be interpreted as a direct test (which is accepted) of the relevance of the latter.

${ }^{15}$ Also note that the results for the 79 country sample (Table A1, column 2) and the 147 country sample (Table 3 , column 5) in the main text are quite similar.

${ }^{16}$ Note that the condition in (AC3) also assumes that the effects of own institutions, $\gamma$, and neighboring institutions, $\lambda$, are not equal to zero.
} 


$$
E\left(\left(W^{k} \varepsilon\right)^{\prime} \varepsilon\right) \neq 0 \quad \text { for at least one } k \in\{1,2,3, \ldots\}
$$

For $k=1$, this will be the case if random shocks to GDP per capita are spatially correlated among neighbors. We think one can expect this to be the case, think of for example shocks due to reasons of climate, which thus already suggests the need to instrument spatial institutions. This need is even more clearly established by noting that for values of $k>1$, condition (AC3) will always be true as those terms involve the variance of $\varepsilon$ which is clearly not equal to zero (in the case of for example $\mathrm{k}=2$, the term in (AC3) will represent the correlation of a country's own shock with the shock to that country's neighbors' neighbors, which clearly includes the country's own shock).

\section{Measurement error}

Can we expect our institutional variable to be measured with error, i.e.

$$
\left(\text { W Inst }_{i}\right)^{\text {TRUE }}=\text { W Inst }_{i}+v_{i}
$$

If so the need to instrument would be evident and not instrumenting would result (given the fact that the coefficient is positive when using OLS, see Table 3) in a downward bias. One can, however, also argue that the measurement error is completely due to mismeasuring the institutional quality, Inst, and not so much the spatial structure, $W$. If this is the case, measurement error in the institutional variable has its effect on the neighboring institutional measure only through, Inst, i.e. (AC4) becomes:

$$
\left(\text { W Inst }_{i}\right)^{\text {TRUE }}=W\left(\text { Inst }_{i}+v_{i}\right)=W \text { Inst }_{i}+W v_{i}
$$

Although only subtly different from the case in (AC4) this type of measurement error is in our view even more likely to be present (see Acemoglu, et al. (2001), who view (based on the difference in the estimated parameter of institutions when using OLS or 2SLS) measurement error in own institutions as the main source of endogeneity). It is straightforward to show that, as in the case of (AC4), this type of measurement error leads to a downward bias in the estimated coefficient when simply using OLS. Hereby establishing, in our view even more firmly than in the case of reverse causality, the need to instrument neighboring institutions.

3. Omitted variables

If we expect the presence of an omitted variable that explains GDP per capita and that is correlated to our measure of institutional quality, the need to instrument would immediately be present. This is clearly not unthinkable in the case of neighboring institutions. Instead of instrumenting, however, one would much rather include the important omitted variable in the regression. The latter is what is done in the numerous robustness checks provided in the main text. But, of course, one cannot include variables in these robustness checks for which no data is available. So instrumenting neighboring institutions on the basis of omitted variable bias is also a valid reason, maybe not that a convincing reason though as omitted variable bias can be argued to be a problem in any empirical study (and clearly IV-estimation is not so common in many studies).

Given that we need to instrument, we will now show that neighboring 'fitted institutions' constructed by multiplying 'fitted institutions' obtained from the first stage, (2-i), by the spatial weight matrix, $W$, is a valid way to solve the endogeneity problems involved in the neighboring institutions variable. For ease of exposition we will show this for the following case (in vector notation) ${ }^{17}$ :

\footnotetext{
${ }^{17}$ The result is easily extended to including also $\mathrm{X}$, the endogenous variable in nonspatial form, and/or other endogenous/exogenous variables. One can also generalise the result regarding the variance and allow for heteroscedasticity of $\varepsilon$.
} 

ii) $Y=\alpha W X+\varepsilon$
i) $\quad X=\beta Z+\eta$

where $\mathrm{Y}$ is the dependent variable, WX is a spatial measure based on spatial weight matrix W and variable $X$, and to solve possible endogeneity problems $X$ is instrumented by the instrumental variable $Z$. It is assumed that $Z$ is a valid instrument, i.e. $\beta \neq 0$ and $E\left(Z^{\prime} \varepsilon\right)=0$, and that $E\left(Z^{\prime} \eta\right)=0$. The fitted values of $\mathrm{X}$ obtained from the first stage, (AC6-i) are

$$
\hat{X}=Z\left(Z^{\prime} Z\right)^{-1} Z^{\prime} X
$$

substituting this for $\mathrm{X}$ in the $2^{\text {nd }}$ stage (AC6-ii) and doing the regression gives the following estimate of $\alpha$ :

$$
\hat{\alpha}=\left(\hat{X}^{\prime} W^{\prime} W \hat{X}\right)^{-1} \hat{X}^{\prime} W^{\prime} Y
$$

Is this estimate unbiased, i.e. is $E(\hat{\alpha})=\alpha$ ? This can be checked rewriting (AC8) by first substituting (AC6-ii) for and $\mathrm{Y}$ and adding and substracting $\alpha W \hat{X}$ :

$$
\hat{\alpha}=\left(\hat{X}^{\prime} W^{\prime} W \hat{X}\right)^{-1} \hat{X}^{\prime} W^{\prime}(\alpha W X+\varepsilon+\alpha W \hat{X}-\alpha W \hat{X})
$$

which simplifies to

$$
\hat{\alpha}=\alpha+\left(\hat{X}^{\prime} W^{\prime} W \hat{X}\right)^{-1} \hat{X}^{\prime} W^{\prime} \varepsilon+\left(\hat{X}^{\prime} W^{\prime} W \hat{X}\right)^{-1} \hat{X}^{\prime} W^{\prime} \alpha W(X-\hat{X})
$$

Next rewrite $(X-\hat{X})$ using (AC7) and (AC6-ii) to get:

$$
\hat{\alpha}=\alpha+\left(\hat{X}^{\prime} W^{\prime} W \hat{X}\right)^{-1} \hat{X}^{\prime} W^{\prime} \varepsilon+\left(\hat{X}^{\prime} W^{\prime} W \hat{X}\right)^{-1} \hat{X}^{\prime} W^{\prime} \alpha W\left(I-Z\left(Z^{\prime} Z\right)^{-1} Z^{\prime}\right) \eta
$$

Now it can be established, by substituting (AC7) for $\hat{X}$, taking the expectation, and using the assumptions that $E\left(Z^{\prime} \varepsilon\right)=0$ and $E\left(Z^{\prime} \eta\right)=0$, that:

$$
E(\hat{\alpha})=\alpha
$$

Having established the unbiasedness of the estimated parameter, $\hat{\alpha}$, we are also interested in the accuracy of the estimated parameter, $\operatorname{Var}(\hat{\alpha})$ ? Using (AC11) and denoting $P=\left(\hat{X}^{\prime} W^{\prime} W \hat{X}\right)^{-1} \hat{X}^{\prime} W^{\prime}$ and $R=\left(\hat{X}^{\prime} W^{\prime} W \hat{X}\right)^{-1} \hat{X}^{\prime} W^{\prime} W\left(I-Z\left(Z^{\prime} Z\right)^{-1} Z^{\prime}\right)$ it can be shown that:

$\operatorname{Var}(\hat{\alpha})=\sigma_{\varepsilon}^{2}\left(\hat{X}^{\prime} W^{\prime} W \hat{X}\right)^{-1}+\alpha^{2} \sigma_{\eta}^{2} R R^{\prime}+2 \alpha \sigma_{\varepsilon \eta} P R^{\prime}$

where $\sigma_{\varepsilon}^{2}, \sigma_{\eta}^{2}$ is the variance of $\varepsilon, \eta$ respectively and $\sigma_{\varepsilon \eta}$ the covariance between $\varepsilon$ and $\eta$. (AC13) can be estimated consistently by substituting $\hat{\sigma}_{\varepsilon}^{2}, \hat{\sigma}_{\eta}^{2}, \hat{\sigma}_{\varepsilon \eta}$ and $\hat{\alpha}$ for $\sigma_{\varepsilon}^{2}, \sigma_{\eta}^{2}, \sigma_{\varepsilon \eta}$ and $\alpha$ respectively. 


\title{
CESifo Working Paper Series
}

\author{
(for full list see www.cesifo-group.de)
}

1705 Piero Gottardi and Felix Kubler, Social Security and Risk Sharing, April 2006

1706 Giacomo Corneo and Christina M. Fong, What's the Monetary Value of Distributive Justice?, April 2006

1707 Andreas Knabe, Ronnie Schoeb and Joachim Weimann, Marginal Employment Subsidization: A New Concept and a Reappraisal, April 2006

1708 Hans-Werner Sinn, The Pathological Export Boom and the Bazaar Effect - How to Solve the German Puzzle, April 2006

1709 Helge Berger and Stephan Danninger, The Employment Effects of Labor and Product Markets Deregulation and their Implications for Structural Reform, May 2006

1710 Michael Ehrmann and Marcel Fratzscher, Global Financial Transmission of Monetary Policy Shocks, May 2006

1711 Carsten Eckel and Hartmut Egger, Wage Bargaining and Multinational Firms in General Equilibrium, May 2006

1712 Mathias Hoffmann, Proprietary Income, Entrepreneurial Risk, and the Predictability of U.S. Stock Returns, May 2006

1713 Marc-Andreas Muendler and Sascha O. Becker, Margins of Multinational Labor Substitution, May 2006

1714 Surajeet Chakravarty and W. Bentley MacLeod, Construction Contracts (or "How to Get the Right Building at the Right Price?”), May 2006

1715 David Encaoua and Yassine Lefouili, Choosing Intellectual Protection: Imitation, Patent Strength and Licensing, May 2006

1716 Chris van Klaveren, Bernard van Praag and Henriette Maassen van den Brink, Empirical Estimation Results of a Collective Household Time Allocation Model, May 2006

1717 Paul De Grauwe and Agnieszka Markiewicz, Learning to Forecast the Exchange Rate: Two Competing Approaches, May 2006

1718 Sijbren Cnossen, Tobacco Taxation in the European Union, May 2006

1719 Marcel Gérard and Fernando Ruiz, Interjurisdictional Competition for Higher Education and Firms, May 2006 
1720 Ronald McKinnon and Gunther Schnabl, China's Exchange Rate and International Adjustment in Wages, Prices, and Interest Rates: Japan Déjà Vu?, May 2006

1721 Paolo M. Panteghini, The Capital Structure of Multinational Companies under Tax Competition, May 2006

1722 Johannes Becker, Clemens Fuest and Thomas Hemmelgarn, Corporate Tax Reform and Foreign Direct Investment in Germany - Evidence from Firm-Level Data, May 2006

1723 Christian Kleiber, Martin Sexauer and Klaus Waelde, Bequests, Taxation and the Distribution of Wealth in a General Equilibrium Model, May 2006

1724 Axel Dreher and Jan-Egbert Sturm, Do IMF and World Bank Influence Voting in the UN General Assembly?, May 2006

1725 Swapan K. Bhattacharya and Biswa N. Bhattacharyay, Prospects of Regional Cooperation in Trade, Investment and Finance in Asia: An Empirical Analysis on BIMSTEC Countries and Japan, May 2006

1726 Philippe Choné and Laurent Linnemer, Assessing Horizontal Mergers under Uncertain Efficiency Gains, May 2006

1727 Daniel Houser and Thomas Stratmann, Selling Favors in the Lab: Experiments on Campaign Finance Reform, May 2006

1728 E. Maarten Bosker, Steven Brakman, Harry Garretsen and Marc Schramm, A Century of Shocks: The Evolution of the German City Size Distribution 1925 - 1999, May 2006

1729 Clive Bell and Hans Gersbach, Growth and Enduring Epidemic Diseases, May 2006

1730 W. Bentley MacLeod, Reputations, Relationships and the Enforcement of Incomplete Contracts, May 2006

1731 Jan K. Brueckner and Ricardo Flores-Fillol, Airline Schedule Competition: ProductQuality Choice in a Duopoly Model, May 2006

1732 Kerstin Bernoth and Guntram B. Wolff, Fool the Markets? Creative Accounting, Fiscal Transparency and Sovereign Risk Premia, May 2006

1733 Emmanuelle Auriol and Pierre M. Picard, Government Outsourcing: Public Contracting with Private Monopoly, May 2006

1734 Guglielmo Maria Caporale and Luis A. Gil-Alana, Modelling Structural Breaks in the US, UK and Japanese Unemployment Rates, May 2006

1735 Emily J. Blanchard, Reevaluating the Role of Trade Agreements: Does Investment Globalization Make the WTO Obsolete?, May 2006

1736 Per Engström and Bertil Holmlund, Tax Evasion and Self-Employment in a High-Tax Country: Evidence from Sweden, May 2006 
1737 Erkki Koskela and Mikko Puhakka, Cycles and Indeterminacy in Overlapping Generations Economies with Stone-Geary Preferences, May 2006

1738 Saku Aura and Thomas Davidoff, Supply Constraints and Housing Prices, May 2006

1739 Balázs Égert and Ronald MacDonald, Monetary Transmission Mechanism in Transition Economies: Surveying the Surveyable, June 2006

1740 Ben J. Heijdra and Ward E. Romp, Ageing and Growth in the Small Open Economy, June 2006

1741 Robert Fenge and Volker Meier, Subsidies for Wages and Infrastructure: How to Restrain Undesired Immigration, June 2006

1742 Robert S. Chirinko and Debdulal Mallick, The Elasticity of Derived Demand, Factor Substitution and Product Demand: Corrections to Hicks' Formula and Marshall's Four Rules, June 2006

1743 Harry P. Bowen, Haris Munandar and Jean-Marie Viaene, Evidence and Implications of Zipf's Law for Integrated Economies, June 2006

1744 Markku Lanne and Helmut Luetkepohl, Identifying Monetary Policy Shocks via Changes in Volatility, June 2006

1745 Timo Trimborn, Karl-Josef Koch and Thomas M. Steger, Multi-Dimensional Transitional Dynamics: A Simple Numberical Procedure, June 2006

1746 Vivek H. Dehejia and Yiagadeesen Samy, Labor Standards and Economic Integration in the European Union: An Empirical Analysis, June 2006

1747 Carlo Altavilla and Paul De Grauwe, Forecasting and Combining Competing Models of Exchange Rate Determination, June 2006

1748 Olaf Posch and Klaus Waelde, Natural Volatility, Welfare and Taxation, June 2006

1749 Christian Holzner, Volker Meier and Martin Werding, Workfare, Monitoring, and Efficiency Wages, June 2006

1750 Steven Brakman, Harry Garretsen and Charles van Marrewijk, Agglomeration and Aid, June 2006

1751 Robert Fenge and Jakob von Weizsäcker, Mixing Bismarck and Child Pension Systems: An Optimum Taxation Approach, June 2006

1752 Helge Berger and Michael Neugart, Labor Courts, Nomination Bias, and Unemployment in Germany, June 2006

1753 Chris van Klaveren, Bernard van Praag and Henriette Maassen van den Brink, A Collective Household Model of Time Allocation - a Comparison of Native Dutch and Immigrant Households in the Netherlands, June 2006 
1754 Marko Koethenbuerger, Ex-Post Redistribution in a Federation: Implications for Corrective Policy, July 2006

1755 Axel Dreher, Jan-Egbert Sturm and Heinrich Ursprung, The Impact of Globalization on the Composition of Government Expenditures: Evidence from Panel Data, July 2006

1756 Richard Schmidtke, Private Provision of a Complementary Public Good, July 2006

1757 J. Atsu Amegashie, Intentions and Social Interactions, July 2006

1758 Alessandro Balestrino, Tax Avoidance, Endogenous Social Norms, and the Comparison Income Effect, July 2006

1759 Øystein Thøgersen, Intergenerational Risk Sharing by Means of Pay-as-you-go Programs - an Investigation of Alternative Mechanisms, July 2006

1760 Pascalis Raimondos-Møller and Alan D. Woodland, Steepest Ascent Tariff Reforms, July 2006

1761 Ronald MacDonald and Cezary Wojcik, Catching-up, Inflation Differentials and Credit Booms in a Heterogeneous Monetary Union: Some Implications for EMU and new EU Member States, July 2006

1762 Robert Dur, Status-Seeking in Criminal Subcultures and the Double Dividend of ZeroTolerance, July 2006

1763 Christa Hainz, Business Groups in Emerging Markets - Financial Control and Sequential Investment, July 2006

1764 Didier Laussel and Raymond Riezman, Fixed Transport Costs and International Trade, July 2006

1765 Rafael Lalive, How do Extended Benefits Affect Unemployment Duration? A Regression Discontinuity Approach, July 2006

1766 Eric Hillebrand, Gunther Schnabl and Yasemin Ulu, Japanese Foreign Exchange Intervention and the Yen/Dollar Exchange Rate: A Simultaneous Equations Approach Using Realized Volatility, July 2006

1767 Carsten Hefeker, EMU Enlargement, Policy Uncertainty and Economic Reforms, July 2006

1768 Giovanni Facchini and Anna Maria Mayda, Individual Attitudes towards Immigrants: Welfare-State Determinants across Countries, July 2006

1769 Maarten Bosker and Harry Garretsen, Geography Rules Too! Economic Development and the Geography of Institutions, July 2006 